\title{
Experiential Marketing Starbucks Level Core, Forward, Dan Reserve
}

\author{
Evelyn Thelia, Wulan Purnama Sari \\ evelyn.915150089@stu.untar.ac.id,Wulanp@fikom.untar.ac.id
}

Fakultas Ilmu Komunikasi Universitas Tarumanagara

\begin{abstract}
This study describes the Experiential Marketing Starbucks at the core, forward, and reserve levels. This study uses a case study qualitative research method which uses two theories. The main theory is experiential marketing and marketing communication as the theory of supporting writers. Experiential Marketing is marketing by using positive experiences that are given to consumers with the aim of providing mutually integrated experience, which deals with sense, feel, think, act, and relate. Where the purpose of this study is to notify readers about the differences at Starbucks that are distinguished by the experience given at each level. The results of the study refer to the existence of marketing communication techniques carried out by Starbucks in order to reach all levels of society to get an increase in profits for the company
\end{abstract}

Keywords: Experiential Marketing, Marketing Communication, Starbucks

\begin{abstract}
Abstrak
Penelitian ini menjelaskan mengenai Experiential Marketing Starbucks pada tingkat core, forward, dan reserve. Penelitian ini menggunakan metode penelitian kualitatif studi kasus dimana menggunakan dua teori. Teori utama merupakan experiential marketing dan komunikasi pemasaran sebagai teori pendukung penulis. Experiential Marketing merupakan pemasaran dengan menggunakan pengalaman positif yang diberikan kepada konsumen dengan tujuan memberikan experience yang saling terintegrasi, yang berkenaan dengan sense, feel, think, act, dan relate. Dimana tujuan penelitian ini untuk memberitahukan kepada pembaca mengenai perbedaan pada Starbucks yang dibedakan dengan pengalaman yang diberikan pada setiap levelnya. Hasil dari penelitian merujuk kepada adanya teknik komunikasi pemasaran yang dilkukan Starbucks guna menggapai seluruh lapisan masyarakat untuk mendapatkan peningkatan profit bagi perusahaan.
\end{abstract}

Kata Kunci: Experiential Marketing, Komunikasi Pemasaran, Starbucks

\section{Pendahuluan}

Tren minum kopi di Indonesia sekarang sudah berubah menjadi gaya hidup bagi sebagian masyarakat Indonesia bisa dibuktikan dengan banyaknya gerai-gerai toko kopi yang mulai bermunculan di Indonesia. Dari kedai kecil hingga yang sudah besar. Berdasarkan data Euromonitor pada 2016 menunjukkan, jumlah gerai kopi retail dan specialty coffee meningkat dua kali lipat selama lima tahun terakhir, masing-masing sebanyak 1.025 dan 1.083 buah ( Safira Maharani, 2018)

Minum kopi juga harus didukung dengan tempat yang nyaman untuk nongkrong atau untuk duduk dengan waktu yang lama. Toko kopi merupakan pilihan pertama bagi masyarakat Indonesia untuk kumpul bersama teman, kerabat, keluarga, atau pun untuk bersantai untuk diri sendiri,sehingga tempat dan suasana dari toko kopi sangat penting bagi para konsumennya. Salah satu gerai kopi yang paling 
banyak cabang dan sudah terkenal diberbagai kalangan adalah Starbucks dengan logo siren atau putri duyung.

Misi Starbucks yang unik untuk menginspirasi dan memelihara semangat manusia. Artinya Starbucks tidak hanya menjual kopi tetapi dari usahanya yang terus berkembang. Starbucks ingin menginspirasi masyarakat bahwa ini bukan sekedar bisnis. Tapi dengan adanya hubungan dan relasi yang baik antara para barista dengan pelanggan di dalam lingkungan yang sama meski hanya mencakup 1 gelas kopi atau minuman. Mereka dapat berkembang pesat dengan masyarakat sekitarnya.

Penulis juga menggunakan penelitian terdahulu mengenai Starbucks dan Experiental Marketing, terkait dengan kepuasan dan loyalitas. Penelitian ini memiliki kesamaan dengan penelitian yang sedang diteliti oleh penulis yaitu meneliti mengenai bagimana suatu brand memasarkan produknya dengan menggunakan pengalaman yang dapat membangun hubungan dengan pelanggan sehingga dapat menarik kepuasan dan membangun loyalitas pelanggan. Perbedaannya pada penelitian ini lebih membahas hubungan experiental marketing, kepuasan pelanggan, loyalitas di Starbucks yang terdapat di Surabaya Town Square, sedangkan penulis membahas bagaimana komparasi experiential marketing Starbucks pada tahap core, forward, Reserve.

\section{Metode Penelitian}

Metode penelitian kualitatif mengedepankan peneliti sebagai instrument utama, kemudian hasil penelitian lebih menekan makna dari pada generalisasi (Sugiyono ,2010). Jenis penelitian yang digunakan dalam melakukan penelitian ini adalah penelitian studi kasus, dimana studi kasus menekankan pada fenomena kehidupan nyata. (Yin, 2013) Penulis menggunakan studi kasus karena penulis meneliti kasus yang terjadi di Starbucks dan untuk mendapatkan gambaran secara menyeluruh dari kasusnya. Datadiperoleh melalui wawancara dan observasi. Narasumber berjumlah tiga orang, dimana semuanya merupakan manager di gerai Strabucks.

\section{Hasil Temuan dan Diskusi}

Penulis mengumpulkan data melalui pengamatan langsung dan wawancara Starbucks mengembangkan brandnya dengan menjual pengalaman yang dibuat berbeda pada setiap levelnya. Oleh karena itu adanya experience bar pada Starbucks Coffee Forward dan Starbucks Coffee Reserve guna untuk memberikan experience lebih kepada konsumen. Pada experience bar konsumen yang datang dapat duduk dan memesan kopi sesuai yang mereka inginkan, lalu mereka akan disuguhkan sebuah atraksi dari barista Starbucks cara membuat kopi menggunakan tiga alat yang telah disediakan Starbucks yaitu pour over, chemex, dan syphon. Pengalaman tersebut dapat dirasakan konsumen menggunakan pancaindera mereka. Mereka dapat merasakan dengan sense, feel, think, act, dan relate.

Sesuai teori experiential marketing menurut Schmitt (1999) yang mengatakan bahwa experiential marketing dapat terjadi dimana saja. Hampir setiap sektor industri menerapkan konsep pengalaman ini, mulai dari sektor penghasil barang, produksi kemasan, sampai industry teknologi. Konsep pemasaran yang mengedepankan pengalaman ini dapat berfungsi dalam mengembangkan produk 
baru, berinteraksi dengan pelanggan, membangun relasi penjualan, merancang ruang detail, dan membangun sebua situs.

Starbucks selalu mengembangkan produk baru mereka dengan mengeluarkan minuman, makanan, merchandise, hingga whole bean pada musim tertentu dan bahkan untuk reserve sendiri selalu mengeluarkan biji kopi yang langka yang dapat diseduh. Starbucks selalu meningkatkan relasi mereka kepada customer dengan mengintegrasikan unsur-unsur emosi, logika dan proses pemikiran umum yang dapat membangun hubungan dengan pelanggan sehingga mereka akan dapat merasakan bahwa mereka bukan hanya sekedar customer tetapi sahabat atau rekan.

Terbukti dengan standard pelayanan yang dimiliki Starbucks yaitu make every customer feel special dengan smile and make eye contact, melayani dengan ramah, genuine greeting, learn customer's names and orders, mengucapkan terima kasih, dan make every moment right. Dimana dengan produk dan pelayanan yang diberikan Starbucks kepada customersnya telah mencakup semua tujuan dari experiential marketing yaitu menciptakan sebuah pengalaman yang positif melalui implementasi kelima modul strategic experiential modules ( SEMs) yang berkenaan dengan sense, feel, think, act, dan relate. Dengan satu individu, satu cangkir, dan satu lingkungan Starbucks memberikan pengalaman yang tidak terlupakan oleh customersnya.

Penulis menemukan bahwa sebenarnya adanya pembagian level seperti core, forward, dan reserve hanyalah bagian dari komunikasi pemasaran saja. Dimana guna menggapai semua customers dari berbagai kalangan, dari yang tidak suka kopi hingga yang suka kopi hitam, dari yang ingin biasa-biasa saja sampai yang terlihat mewah dan berkelas. Menurut Tjiptono (2011) Komunikasi pemasaran merupakan aktivitas pemasaran yang berusaha menyebarkan informasi, mempengaruhi/membujuk, dan mengingatkan pasar sasaran atas perusahaan dan produknya agar bersedia menerima, membeli, loyal pada produk yang ditawarkan perusahaan yang bersangkutan. Tujuan komunikasi pemasaran pada dasarnya adalah memberikan efek kognitif, yaitu membentuk kesadaran informasi tertentu dalam benak pelanggan. Efek afektif, yaitu memberikan pengaruh untuk melakukan sesuatu yang diharapkan adalah reaksi pembelian dari pelanggan. Efek konatif atau perilaku, yaitu membentuk pola khalayak menjadi perilaku selanjutnya. Perilaku yang diharapkan adalah pembelian ulang.

Core, forward, dan reserve secara tidak langsung membentuk kesadaran infromasi kepada customers mengenai adanya perbedaan experience pada masingmasing levelnya yang memberikan pengaruh dalam melakukan sesuatu yaitu reaksi pembelian dan akhirnya membentuk pola customers menjadi perilaku selanjutnya yang diharapkan melakukan pembelian ulang sesuai dengan keinginan dari customers dan dengan adanya pembagian core, forward, dan reserve memberikan kemudahan bagi customersnya yang ingin membeli produk karena dapat memilih sesuai dengan keperluan dan keinginan mereka.

Ketika mereka hanya ingin meminum kopi biasa atau frappucino mereka bisa hanya mendatangi Starbucks Coffee Core yang pastinya mudah ditemui. Ketika mereka ingin meminum kopi hitam dengan biji kopi yang akan selalu tersedia tetapi dengan cara yang unik mereka bisa mendatangi Starbucks Coffee Forward. Tetapi, ketika mereka menginginkan kopi hitam dengan biji kopi langka atau latte dengan espresso yang berbeda dengan biasanya mereka bisa mendatangi Starbucks Coffee Reserve sekaligus disini mereka bisa merasakan suasana yang elegan dan homey yang pastinya berbeda dengan Starbucks lainnya. 
Experiental Marketing terdiri dari 5 elemen yaitu sense, feel, think, act, dan relate.

- Sense

Sense diperuntukkan terhadap rasa dengan tujuan menggunakan pancaindera melalui kelima indra yang terdapat pada manusia, yaitu penglihatan, pendengaran, penciuman, pengecapan, dan perabaan.

Tabel 1. Perbedaan Sense

\begin{tabular}{|c|c|c|c|}
\hline & CORE & FORWARD & RESERVE \\
\hline Penglihatan & $\begin{array}{c}\text { Kecil-standard, } \\
\text { domininasi green } \\
\text { apron }\end{array}$ & $\begin{array}{l}\text { Lebih luas dan } \\
\text { nyaman, dominasi } \\
\text { black apron }\end{array}$ & $\begin{array}{c}\text { Elegant dan classy, } \\
\text { Lambang R, Black } \\
\text { Eagle, Semua } \\
\text { black apron }\end{array}$ \\
\hline Penciuman & $\begin{array}{c}\text { Bau biji kopi yang } \\
\text { tidak terlalu kuat }\end{array}$ & $\begin{array}{c}\text { Bau biji kopi yang } \\
\text { cukup kuat }\end{array}$ & $\begin{array}{c}\text { Bau biji kopi yang } \\
\text { unik }\end{array}$ \\
\hline Pengecapan & $\begin{array}{l}\text { Rasa standard } \\
\text { Starbucks }\end{array}$ & $\begin{array}{l}\text { Rasa yang sesuai } \\
\text { dengan lidah } \\
\text { (custom made) }\end{array}$ & $\begin{array}{l}\text { Rasa unik yang } \\
\text { tidak akan ditemui } \\
\text { dilevel lain }\end{array}$ \\
\hline
\end{tabular}

- Feel

Merupakan perasaan positif yang muncul dari dalam hati dan perasaan gembira yang terjadi pada saat mengonsumsi suatu barang atau jasa. Core konsumen akan datang dan membeli minuman kesukaan atau yang mereka inginkan. Jika di Forward konsumen dapat mencoba hal baru yaitu manual brew. Reserve disini konsumen dapat mencoba minuman dengan biji kopi yang langka yang pastinya tidak dapat dicoba di level lain.

- Think

Tujuan think marketing adalah mendorong konsumen untuk ikut serta dalam proses kerja sama dan berfikir kreatif, yang berdampak pada penilaian kembali konsumen terhadap suatu produk dan perusahaannya. Cara Starbucks Core memperkenalkan minuman baru mereka dengan cara sampling dan biasanya sambil memberikan informasi mengenai promo yang sedang berlangsung. Forward cara mereka memperkenalkan adanya manual brew dengan sampling manual brew. Jika reserve karena mereka memiliki biji kopi yang langka biasanya mereka melakukan coffee talk dengan konsumen. Ratarata konsumen di reserve merupakan pecinta kopi dan berani bayar mahal untuk kopi itu sendiri.

- Act

Berbicara mengenai pengalaman konsumen yang terkait dengan bagian fisik dari tubuh, pola perilaku jangka panjang dan gaya hidup, serta pengalaman yang terjadi akibat berkomunikasi dengan orang lain. Untuk Starbucks Core akan lebih mudah kita temui dimana-mana sehingga ia berhasil menerapkan adanya third place bagi masyarakat. Dengan adanya manual brew membuat forward dapat lebih intim berinteraksi dengan konsumen tanpa terhalang adanya mesin espresso. Reserve memiliki suasana yang classy dan elegant lalu mempunyai biji kopi yang langka (seasonal) sehingga konsumen menjadi lebih konsumtif. Karena dengan adanya biji kopi yang langka ini pasti mereka tau harganya akan lebih mahal ketimbang yang biasa.

- Relate 
Relate marketing membuat seseorang ingin dipandang secara positif oleh orang lain. Ketika konsumen datang ke Core mereka akan mencoba dan membeli minuman brand putri duyung ini. walaupun beberapa harga dapat dikatakan mahal tetapi mereka tetap mencoba untuk mendapatkan semacam pengakuan positif bahwa mereka telah mencoba minuman di Starbucks. Forward karena terkenal dengan adanya manual brew membuat konsumen yang pecinta kopi hitam berlomba-lomba untuk mencobanya. Reserve karena memiliki mesin black eagle yang cukup menarik perhatian dan memiliki biji kopi langka membuah pencinta kopi hitam dan kopi susu berlomba-lomba untuk mencobanya walaupun harus membayar lebih mahal dari yang biasanya.

\section{Simpulan}

Kesimpulan setelah melakukan observasi dan wawancara penulis menemukan bahwa memang adanya perbedaan dari Starbucks Coffee Core, Starbucks Coffee Forward, dan Starbucks Coffee Reserve yaitu pengalaman yang diberikan pada masing-masing level. Perbedaan yang cukup terlihat yaitu pada bar dan produk yang ditawarkan. Penulis menemukan bahwa Starbucks sudah mencakup kelima elemen strategic experiential modules yaitu sense, feel, think, act, dan relate. Experiental marketing adalah sebuah paradigma dalam pemasaran yang berorientasi pada pentingnya pengalaman yang positif bagi konsumen yang memadukan elemenelemen yaitu sense, feel, think, act, dan relate menurut Schmitt (1999). Berdasarkan hasil yang di dapat Starbucks dan berdasarkan teori yang digunakan penulis, Starbucks telah mencakup lima konsep strategi experiential tersebut yaitu sense, feel, think, act, dan relate.

\section{Ucapan Terima Kasih}

Ucapan terima kasih ditujukan kepada seluruh informan yang bersedia dan bekerja sama selama proses penelitian berlangsung. Ucapan terima kasih juga ditujukan kepada keluarga, kerabat, informan, dan teman-teman penulis yang selalu memberi perhatian dan menyemangati penulis dalam menyelesaikan penelitian ini dengan tepat waktu dan tentunya kepada sahabat penulis Rachel Nelly dan Catherine yangbanyak membantu penulis dalam proses penelitian ini dan narasumber yang telah meluangkan waktu dan memberikan informasi yang dibutuhkan penulis.

\section{Daftar Pustaka}

Hadiwidjaja, Reymond Setiabudi, Diah Dharmayanti. (2014). Analisis hubungan experiential marketing kepuasan pelanggan, loyalitas pelanggan Starbucks Coffee di Surabaya Town Square.Volume 2 : 2. https://media.neliti.com/media/publications/134319-ID-analisa-hubunganexperiential-marketing.pdf. ( diakses pada tanggal 27 maret 2019).

Maharani, Safira. (2018). Kopi, Candu Masa Kini. https://kumparan.com/@kumparanfood/kopi-candu-masa-kini. Diakses pada 15 Maret 2019). 
Vol. 3, No. 1, Juli 2019, Hal 80-85

Schmitt, Bernd.H. (1999). Experiential Marketing : How to Get Customer to Sense, Feel, Think, Act, Relate, to Your Company and Brands. New York : The Free Press.

Sugiyono. (2010). Metodologi Penelitian Bisnis. ( Pendekatan Kuantitatif, Kualitatif, $R \& D$ ). Bandung : Alfabeta.

Tjiptono, Fandy. (2012). Service Management Mewujudkan Layanan Prima. Yogyakarta: CV Andi Offset.

Yin, Robert K. (2013). Studi Kasus Desain dan Metode. Jakarta: PT. Raja Grafindo Persada. 